\title{
Effect of hand-hoe based conservation agriculture on soil fertility and maize yield in selected smallholder areas in Zimbabwe
}

\author{
Justice Nyamangara*, Esther Nyaradzo Masvaya, Ronald Tirivavi, Kudzai Nyengerai \\ International Crops Research Institute for the Semi-Arid Tropics, Matopos Research Station, P.O. Box 776, Bulawayo, Zimbabwe
}

\section{A R T I C L E I N F O}

\section{Article history:}

Received 13 March 2012

Received in revised form 25 July 2012

Accepted 31 July 2012

\section{Keywords:}

Conventional tillage

Crop residues

Reduced tillage

Smallholder farming

Soil fertility

Soil properties

\begin{abstract}
A B S T R A C T
Conservation agriculture (CA) based on hand-hoe prepared planting basins is being widely promoted in southern Africa, targeting resource-constrained farmers with limited access to draft power. This study was conducted across 15 districts covering four agro-ecological zones in Zimbabwe where paired CA and conventional animal drawn tillage (CADT) plots had been established on 450 farms as part of CA promotion. The aim of the study was to assess the effect of CA on soil pH, organic C, total P and maize (Zea mays L.) grain yield compared with CADT, and also to evaluate the yield benefits of mulching and crop rotation in CA with or without mineral fertilizer use. It was hypothesized that CA improved the $\mathrm{pH}$, organic C, total P of the soils (Arenosols) and grain yield compared with CADT and that mulching and crop rotation in CA increased maize grain yield. A total of 1014 soil samples (0-0.2 m depth) were taken at the end of the 2009/10 cropping season and analyzed for pH, organic C and total P. Grain yield was determined in 2009/10 and 2010/11 from 0.01 ha net plots. There was no significant difference in average soil $\mathrm{pH}$, total $\mathrm{P}$ and organic $\mathrm{C}$ between $\mathrm{CA}$ and CADT plots and therefore the hypothesis that CA improves these soil properties was rejected. Average concentration for organic $C$ for both CA and CADT plots was less than $10 \mathrm{~g} \mathrm{~kg}^{-1}$, a minimum threshold for well managed soils. When combined with mineral fertilizer: mulching, crop rotation, and mulching + crop rotation in CA increased maize grain yield by 20-33\%, 7-9\% and 58-69\%, respectively. With no mineral fertilizer application, mulching, crop rotation, and mulching + crop rotation depressed maize grain yield by $48 \%$, $28 \%$ and $36 \%$, respectively. Therefore the hypothesis that mulching and crop rotation increase maize grain yield was accepted when mineral fertilizer was added and rejected when the fertilizer was not added. It was concluded that the yield benefits of CA can only be realized when mineral fertilizer is also applied. All the three CA principles in combination with mineral fertilizer results in highest yield benefits compared with one or two principles as currently done by most smallholder farmers in Zimbabwe. Access to mineral fertilizer is an important factor in the targeting of CA promotion in smallholder areas of Zimbabwe and similar socioecological zones in sub-Saharan Africa.
\end{abstract}

(c) 2012 Elsevier B.V. All rights reserved.

\section{Introduction}

Conservation agriculture (CA) refers to a management system of raising crops with minimal soil disturbance while preserving a permanent or semi-permanent organic cover (e.g. crop residues) and adopting spatial and/or temporal crop sequence/rotation. For mechanized cropping systems, benefits of CA include reduced labor, fuel and machinery expenses (Pala et al., 2008). Minimum tillage and preservation of organic soil cover improves soil structural properties and conserves water, and protects soil against water and wind erosion compared with conventional tillage (Madejón et al., 2009; Fuentes et al., 2010). Reduced tillage has also been reported to

\footnotetext{
* Corresponding author. Tel.: +263 383 311; fax: +263 383253 .

E-mail address: j.nyamangara@cgiar.org (J. Nyamangara).
}

reduce greenhouse gas emissions (Hazarika et al., 2009). Conventional tillage mixes soil organic matter in the surface layers and may increase its decomposition and hence gaseous emissions of $\mathrm{CO}_{x}$ and $\mathrm{NO}_{x}$. However, CA has been reported to depress crop yields and this was attributed to cooler and wetter soil conditions, limiting soil physical properties, phytotoxicity from previous crop residues, soil pathogens, increased grassy weeds, residue problems at seeding and decreased fertilizer efficiency (Murillo et al., 1998). A meta-analysis of major long term CA trials conducted worldwide indicated that grain yield was positive when rainfall was below $600 \mathrm{~mm}$ per annum and negative when it was higher compared with conventional tillage, and the authors attributed the trend to water conservation in low rainfall areas under CA and water logging in high rainfall areas (Rusinamhodzi et al., 2011).

Soil organic matter, nutrients, $\mathrm{pH}$ and texture are key determinants of soil quality (Reeves, 1997). Soil organic matter 
is an important indicator of soil fertility and productivity because of its chemical, physical and biological impacts on other soil properties. Soil organic matter can be increased by either increasing $\mathrm{C}$ input or decreasing SOC loss and decomposition and these can be achieved through adopting residue management and reduced tillage. However studies across a wide range of climatic conditions have shown that SOC only increases under CA with increased cropping intensity (Reeves, 1997). Nutrients ensure productivity of both plant and soil micro-organisms while $\mathrm{pH}$ affects the availability of some nutrients and the chemical environment of plant roots and microbes. In Zimbabwe $\mathrm{N}$ and $\mathrm{P}$ are inherently deficient in all soils (Nyamangara et al., 2001) and therefore their management is key in the sustainability of any cropping system. Soil structure is also poorly developed due to a combination of low clay content, high silt content with promotes crusting and continual use with sub-optimal use of fertility inputs (Grant, 1981; Nyamangara et al., 2001).

Sandy soils occupy roughly two thirds of Zimbabwe, especially where smallholder areas are located (Mapfumo and Giller, 2001), but limited portions of highly productive red clay soils (mainly Alfisols) are also found in the smallholder areas. These soils are characterized by inherent deficiency in N, P, S and micronutrients (especially $\mathrm{Zn}$ ) and in sub-humid areas the soils are also highly acidic (Mugwira and Nyamangara, 1998; Nyamangara et al., 2001). Apart from low inherent nutrient content, the sandy soils have low organic matter, water holding capacity, bases and poor soil structure to support crop production. In some areas nutrient imbalances have been reported and attributed to use of suboptimal fertilizer rates and consequent nutrient mining and extreme acidity (Mugwira and Nyamangara, 1998; Zingore et al., 2008). Nutrient deficiencies and imbalances are more acute in the fields of resource poor farmers who do not have access livestock manure and mineral fertilizer, and in outfields which are generally poorly managed by all classes of farmers (Zingore et al., 2008; Masvaya et al., 2010). Efforts to increase the soil organic matter using locally available organic material such as animal manure are limited by poor structure of sandy soils which promote microbial attack. Besides the general infertility, the soils exhibit spatial fertility variability large enough to affect response to fertilization and targeted application of the often limited nutrient resources to preferred portions of the farm has further increased the fertility gradients (Mtambanengwe and Mapfumo, 2005; Zingore et al., 2008; Masvaya et al., 2010). However a meta-analysis of data from CA trials conducted worldwide and for up to forty years indicated that sandy soils responded more positively to CA in terms of maize yield compared with clay soils (Rusinamhodzi et al., 2011).

Worldwide, about 63 million ha of land is under no-till systems and most of the land is in the USA (21.1 million ha) and Brazil (18 million ha) (Metay et al., 2007). In southern Africa, a form of CA which involves digging planting basins using hand hoes and is mainly targeted at resource-constrained households has been actively promoted (Mazvimavi and Twomlow, 2009). In Zambia, where deeper planting basins are promoted in order to break the plough pan, adoption by smallholder farmers has been high (Haggblade and Tembo, 2003). Since 2004, there has been as series of growing initiatives in Zimbabwe to promote CA in smallholder areas through various donor-funded relief and recovery projects and by 2010 about one hundred thousand hectares of land in smallholder areas was under CA (Marongwe et al., 2010).

The CA package being promoted in Zimbabwe is based on preparing permanent planting basins just before the onset of the rains which are large enough (up to $15 \mathrm{~cm}$ deep) to accommodate fertilizer (mineral or organic) and seed, and remain partially covered in order to collect runoff water at the start of the rainy season. In subsequent years the still visible basins are merely reconstructed thereby saving on labor input. Preparation of the basins during the dry season and concentration of runoff water (and nutrients) in the planting basins enables farmers, especially resource-poor farmers who would have to wait for several weeks in order to have their fields ploughed by richer neighbors, to plant early and therefore increase their yield potential. The aim of this study was to assess the effect of $\mathrm{CA}$ on soil $\mathrm{pH}$, organic $\mathrm{C}$, total $\mathrm{P}$ and grain yield in fields that had been under CA for up to nine years in fifteen districts with varying agro-ecological conditions, compared with conventional animal drawn tillage (CADT). We hypothesized that practising CA leads to improvement in soil quality and higher grain yields compared with CADT regardless of agro-ecology.

\section{Materials and methods}

\subsection{Agro-ecological and farming systems in Zimbabwe}

Zimbabwe is divided into five agro-ecological natural regions mainly based on rainfall amount, distribution and reliability (Vincent and Thomas, 1960). Natural region (NR) I receives the highest and most reliable rainfall ( $>1000 \mathrm{~mm}$ per annum) and is characterized by specialized agriculture such as horticulture and dairy (Fig. 1). NR II is most suitable for arable cropping and receives $750-1000 \mathrm{~mm}$ per annum rainfall. It is further divided into NR IIa where rainfall is more uniformly distributed and therefore reliable, and NR IIb where rainfall is less reliable and mid-season droughts may occur. In sub-humid districts (NR II and partly III) the farming system is dominated by maize (Zea mays L.) production with some livestock rearing, and the latter is key for tillage and soil fertility improvement through manure. Rainfall is lowest and least reliable in NRV ( $<450 \mathrm{~mm}$ per annum). In this region livestock are dominant and cropping is limited to drought tolerant crops such as sorghum (Sorghum bicolor L.) and pearl millet (Pannesetum glaucum L.), and frequent droughts often result total crop failure and livestock deaths. Groundnut (Arachis hypogaea L.) and sugar bean (Phaseolus vulgaris L.) are the major legumes in the subhumid areas whereas cowpea (Vigna unguiculata (L.) Walp.) is predominant in the semi-arid areas. Fig. 1 shows the distribution of the sampled districts across the agro-ecological regions IIa-IV. The majority of the districts are covered by sandy soils derived from granitic parent material classified as arenosols according to the IUSS Working Group World Reference Base (2007).

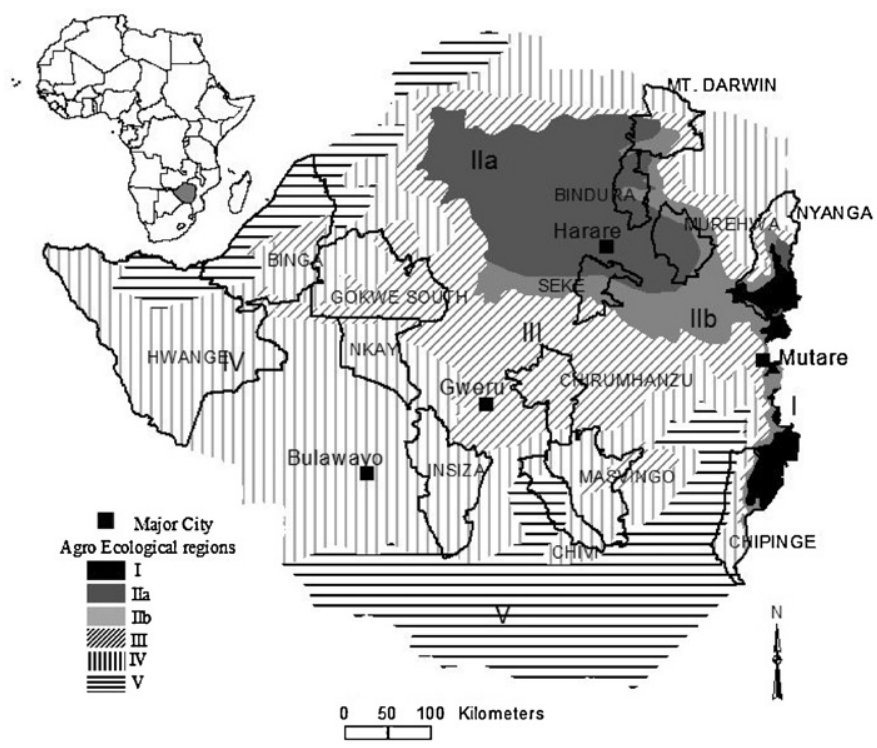

Fig. 1. Location of the 15 districts surveyed and their respective agro-ecological regions in Zimbabwe. 


\subsection{Soil sampling and analysis}

Soil samples were collected from 15 districts (450 farms) of Zimbabwe representing contrasting agro-ecological zones ranging from sub-humid to semi-arid conditions (Fig. 1). These districts were also case studies for promoting CA under the Protracted Relief Program (PRP) (2004-2012), a program meant to promote sustainable crop production in the smallholder areas. In each district 2 wards were selected and from each ward 15 farmers were chosen. These farmers had been practising CA for up to 9 years with guidance of stakeholders in the PRP, mainly non-governmental organizations (NGOs), and technical backstopping from the International Crops Research Institute for the Semi Arid Tropics (ICRISAT).

Household interviews were carried out to understand landholdings, area under CA, number of years after adoption of CA, nutrient inputs, crop rotation, and tillage and crop residue management. Thereafter soil samples (0-0.2 m layer) were collected from both the CA and adjacent CADT fields using a soil auger. In the CA fields two samples were taken, one from inside the planting basin and the other from outside the basins, and in the CADT plots one sample was collected. Each composite sample consisted of six sub-samples. For samples outside the planting basins in CA fields and in CADT fields two sub-samples were collected from intra-row positions and four from inter-row positions. The sub-samples were thoroughly mixed to make a composite sample which was taken to the laboratory for analysis. The soil samples were air-dried, passed through a 2-mm sieve and analyzed according to standard methods (Okalebo et al., 1993).

Soil pH was determined (Orion Research, model 301 pH meter) in a mixture of $20 \mathrm{~g}$ soil and $50 \mathrm{~mL}$ distilled water. Soil organic $\mathrm{C}$ was determined using the dichromate oxidation (with external heat applied) method (Anderson and Ingram, 1993). A 0.5-g sample of air-dried soil, ground to pass through a $0.05-\mathrm{mm}$ sieve, was weighed into a 100-mL digestion tube. A 5-mL aliquot of $166 \mathrm{mM}$ potassium dichromate and $10 \mathrm{~mL}$ of concentrated sulfuric acid were added to the soil. The digestion tube was placed in a digestion block, adjusted to $145^{\circ} \mathrm{C}$, for thirty minutes to allow for oxidation of soil organic C. The suspension was allowed to cool and a 25mLaliquot of distilled water then added before it was transferred into a $250-\mathrm{mL}$ flask. Three drops of 1.10 phenanthroline indicator solution were added and excess dichromate was titrated against aqueous ferrous ammonium sulfate. Organic $\mathrm{C}$ was calculated from the difference between dichromate added to the soil before heating (oxidation) and excess dichromate obtained from the titration. Total $\mathrm{P}$ was determined colorimetrically after Kjeldahl digestion $\left(\mathrm{H}_{2} \mathrm{O}_{2} / \mathrm{HCl}\right)$ of the soil. The results were combined with socioeconomic data collected from the same households using a structured questionnaire, in order to determine the effect of selected household parameters on soil fertility. Data analysis to determine variability of the target soil properties was done using SPSS statistical package.

\subsection{Maize yield}

Maize grain yield was determined in 2009/10 and 2010/11 seasons in both tillage treatments on 0.01 ha net plots and adjusted to $125 \mathrm{~g} \mathrm{~kg}^{-1}$ water content. In 2009/10 many farmers mixed grain from CA and CADT plots before yield was determined. Less than $5 \%$ of the farmers grew sorghum and millet and therefore yield was not determined for these crops. Since all farmers adopted minimum tillage but not mulching and crop rotation, it was possible to compare the effect of mulching, crop rotation and mulching plus crop rotation on maize grain yield. The effect of mulching (and/or crop rotation) was calculated as the difference in grain yield between the minimum tillage + mulching (and/or crop rotation) and the minimum tillage only treatments. The difference was expressed as a percentage of the yield in the minimum tillage treatment.

\section{Table 1}

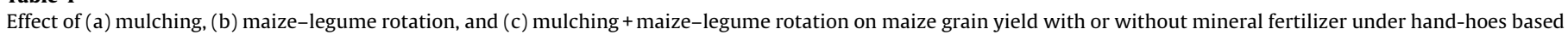
conservation agriculture in the smallholder areas of Zimbabwe. Figures in brackets denote standard error of mean.

\begin{tabular}{|c|c|c|c|c|c|c|c|}
\hline \multicolumn{8}{|l|}{ (a) Mulching effect } \\
\hline Basal NPKS fertilizer $\left(\mathrm{kg} \mathrm{ha}^{-1}\right)$ & \multicolumn{2}{|l|}{ Top dressing $\mathrm{N}$ fertilizer $\left(\mathrm{kg} \mathrm{ha}^{-1}\right)$} & Mulching $^{\mathrm{a}}$ & No. of samples & \multicolumn{2}{|l|}{ Yield ( $\left.\mathrm{kg} \mathrm{ha}^{-1}\right)$} & Mulch effect (\%) \\
\hline 0 & 0 & \multicolumn{2}{|c|}{+} & 10 & \multicolumn{2}{|l|}{$518(133)$} & -48 \\
\hline 0 & 0 & \multicolumn{2}{|c|}{-} & 35 & \multicolumn{2}{|l|}{$767(123)$} & \\
\hline 0 & $132(20)$ & \multicolumn{2}{|c|}{+} & 35 & \multicolumn{2}{|l|}{$1760(247)$} & 33 \\
\hline 0 & $116(11)$ & \multicolumn{2}{|c|}{-} & 62 & \multicolumn{2}{|l|}{$1312(155)$} & \\
\hline $142(9)$ & \multirow{2}{*}{$\begin{array}{l}162(11) \\
162(5)\end{array}$} & \multicolumn{2}{|c|}{+} & 138 & \multicolumn{2}{|l|}{$2564(160)$} & 20 \\
\hline 151(5) & & \multicolumn{2}{|c|}{-} & 316 & \multicolumn{2}{|l|}{ 2063(91) } & \\
\hline \multicolumn{8}{|l|}{ (b) Rotation effect } \\
\hline Basal NPKS fertilizer $\left(\mathrm{kg} \mathrm{ha}^{-1}\right)$ & Top dressing $\mathrm{N}$ fertilizer $\left(\mathrm{kg} \mathrm{ha}^{-1}\right)$ & \multicolumn{2}{|c|}{ Rotation $^{\mathrm{a}}$} & No. of samples & \multicolumn{2}{|l|}{ Yield $\left(\mathrm{kg} \mathrm{ha}^{-1}\right)$} & Rotation effect (\%) \\
\hline 0 & 0 & \multicolumn{2}{|c|}{+} & 13 & \multirow{2}{*}{\multicolumn{2}{|c|}{$\begin{array}{l}509(120) \\
703(168)\end{array}$}} & \multirow[t]{2}{*}{-28} \\
\hline 0 & 0 & - & & 10 & & & \\
\hline 0 & $94(17)$ & \multicolumn{2}{|c|}{+} & 14 & \multicolumn{2}{|l|}{$1639(414)$} & 7 \\
\hline 0 & $126(16)$ & - & & 39 & $1537(166)$ & & \\
\hline $172(15)$ & $189(20)$ & + & & 120 & $2135(154)$ & & 9 \\
\hline $156(8)$ & $167(9)$ & - & & 177 & $1959(106)$ & & \\
\hline (c) Mulching + rotation effect & & & & & & & \\
\hline Basal NPKS fertilizer $\left(\mathrm{kg} \mathrm{ha}^{-1}\right)$ & Top dressing $\mathrm{N}$ fertilizer $\left(\mathrm{kg} \mathrm{ha}^{-1}\right)$ & Rotation $^{\mathrm{a}}$ & Mulch $^{\mathrm{a}}$ & No. of samples & Yield $\left(\mathrm{kg} \mathrm{ha}^{-1}\right)$ & Rotat & $n+$ mulch effect $(\%)$ \\
\hline 0 & 0 & + & + & 5 & $452(61)$ & -36 & \\
\hline 0 & 0 & - & - & 10 & $703(168)$ & & \\
\hline 0 & 187(39) & + & + & 11 & 2423(493) & 58 & \\
\hline 0 & $126(16)$ & - & - & 39 & $1537(166)$ & & \\
\hline $149(25)$ & $167(25)$ & + & + & 26 & $3313(482)$ & 69 & \\
\hline $156(8)$ & $167(9)$ & - & - & 177 & 1959(106) & & \\
\hline
\end{tabular}

\footnotetext{
a +means plus the factor; - means minus factor.
} 


\section{Results and discussion}

The highest maize grain yields were achieved when all the three CA principles were adopted compared with the adoption of one or two principles as currently practised by the smallholder farmers. The effects of mulching and/or legume-based crop rotation on maize grain yield were negative (28-48\%) when mineral fertilizer was not applied and positive (7-69\%) when it was applied (Table $1 \mathrm{a}-\mathrm{c})$. Therefore the promotion of CA should target farmers with access to mineral fertilizer. There was no significant difference in soil $\mathrm{pH}$, organic $\mathrm{C}$ and total $\mathrm{P}$ between $\mathrm{CA}$ and CADT plots although there was a gradual increase in organic $C$ and total $P$ concentrations in CA plots across natural regions with period of practising CA. However, average organic $C$ concentration in both CA and CADT plots was less the $10 \mathrm{~g} \mathrm{~kg}^{-1}$ (Fig. 2), a threshold for well managed soils, implying the fertility status of the soils was low.

\subsection{Soil $p H$, organic $C$ and total $P$}

There was no significant difference in soil $\mathrm{pH}$, organic $\mathrm{C}$ and total $\mathrm{P}$ between $\mathrm{CA}$ and CADT treatments and therefore the hypothesis that $\mathrm{CA}$ improves these properties was rejected. Soil $\mathrm{pH}$ was variable across the natural regions, ranging from very strongly acidic $(\mathrm{pH}<5.0)$ to alkaline $(\mathrm{pH}>7.0)$, and average $\mathrm{pH}$ was lowest in the highest rainfall zone (NR II) and highest in the lowest rainfall zones (NR IV) (Fig. 2). In CA plots, soil pH was marginally higher inside planting basins compared with outside the basins across the
NR. A comparison between pH inside the planting basins (where plants grow) and in CADT plots showed that average $\mathrm{pH}$ was higher in the former (Fig. 2). Soil pH affects nutrient availability and the soil chemical environment which directly affects root growth and microbial biomass (Nyamangara et al., 2000).

Organic $C$ was variable across natural regions and the average concentration was less than $10 \mathrm{~g} \mathrm{~kg}^{-1}$ (Fig. 2), a threshold for well managed soils. Correlations between the difference in organic $C$ concentration between CA and CADT and the period a farmer had been practising CA were weak in all natural regions (Fig. 3). The correlation was only weakly significant in NR III $\left(R^{2}=0.164\right.$, $P=0.06$ ) showing that there was some accumulation in organic $C$ in CA fields relative to CADT fields with experience in CA. Total $P$ was also variable across sampling positions and NRs (Fig. 2). Soils in Zimbabwe are inherently deficient in P (Grant, 1981) and therefore the variability in total $\mathrm{P}$ content was attributed to fertilization with organic or inorganic fertility inputs. Correlations between the difference in total P concentration between $C A$ and CADT and period each farmer has been practising CA was weakly positive across natural regions (Fig. 3 ). The positive correlation was only significant in NR III $\left(R^{2}=0.196, P=0.03\right)$.

The high variability in soil $\mathrm{pH}$, organic $\mathrm{C}$ and total $\mathrm{P}$ across tillage treatments and natural regions was attributed to high variability in the soil types over short distances. Studies have shown that soil fertility variability across smallholder farms in southern and eastern Africa are mainly due to textural differences and preferential and targeted application of the often limited

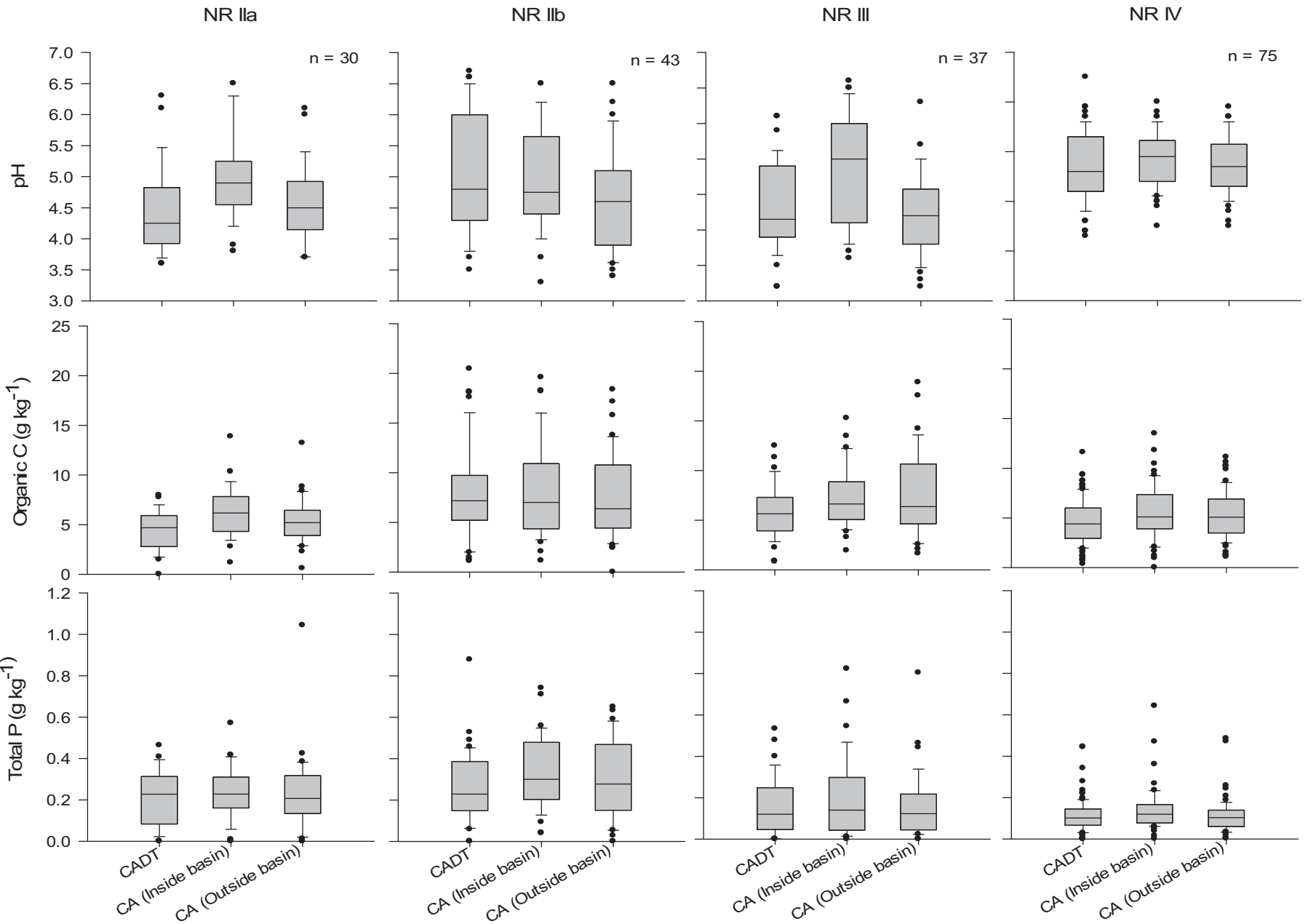

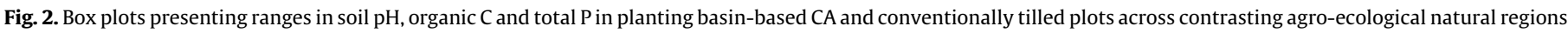
in Zimbabwe. The mean lines present the agro-ecological average of the respective soil property. 


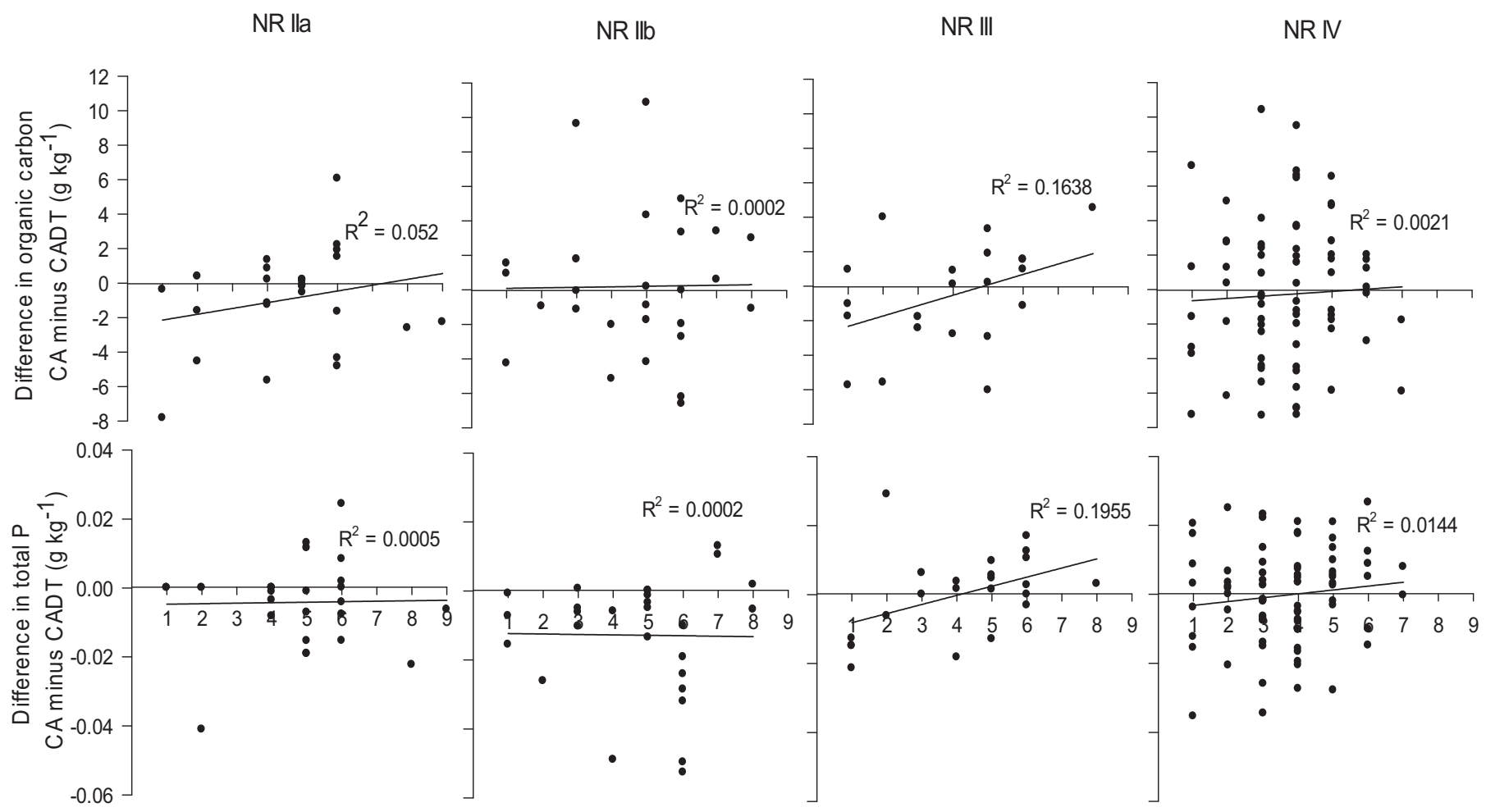

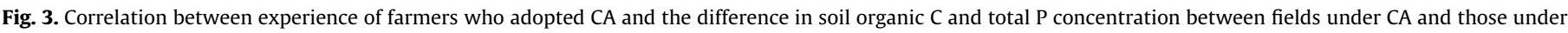
conventional animal drawn tillage (CADT) across contrasting agro-ecological natural regions in Zimbabwe.

nutrient resources to certain preferred parts of the field, especially those near homesteads and cattle pens (Mtambanengwe and Mapfumo, 2005; Tittonell et al., 2005; Masvaya et al., 2010). These variations are more pronounced in fields of resource-constrained farmers, who constitute the majority, than the resource-endowed as the former have limited nutrient resources to apply to their fields (Nyamangara et al., 2011).

The increase in soil $\mathrm{pH}$ from the sub-humid regions (e.g. NR II) to semi-arid regions (e.g. NR V) was expected as more rainfall in the former leaches more basic cations (e.g. $\mathrm{Ca}, \mathrm{Mg}$ ) and these are replaced by less leachable acidic cations $(\mathrm{Al}, \mathrm{H})$. Soil acidity in the higher rainfall areas (NR II in Table 1) has got negative effects on the availability of some key nutrients (e.g. P), microbial activity and root proliferation, and will reduce yield from a high input technology such as CA (Mugwira and Nyamangara, 1998). Farmers who participated in this study were part of a larger survey and were selected based on their low food security and resource endowment status implying that they had limited inputs to improve the fertility of their fields, are less experienced and innovative and therefore manage their fields poorly. Therefore their soils are likely to be more degraded and less responsive to fertilization compared with their resource-endowed and experienced counterparts (Zingore et al., 2008).

Although the studied fields had been under CA for a relatively short period (up to 9 years) and not all three CA principles were implemented by the smallholder farmers, some positive impacts of the practice on organic $\mathrm{C}$, a key soil quality parameter, compared with conventional tillage, were evident (Fig. 3). A meta-analysis of data from CA experiments conducted world-wide for up to four decades indicated that yield benefits from CA began to show after 9-12 years and were most likely in sandy soils than clay soils (Rusinamhodzi et al., 2011). Sandy soils, which constituted the majority of the soils in this study ( $>67 \%$ ), are more responsive to better management (e.g. reduced tillage) (Chivenge et al., 2007) but they degrade equally quickly when management levels decrease, e.g. when reverted back to conventional tillage. Clay soils are more buffered and resilient and therefore will take more time to respond to good management, but are also prone to waterlogging and disease attack in above normal rainfall seasons (Murillo et al., 1998). However the average organic C concentration of less than $10 \mathrm{~g} \mathrm{~kg}^{-1}$ (Fig. 2) in both CA and CADT fields and across all NRs indicated that the fertility of the soils was low (Mugwira and Nyamangara, 1998). Chivenge et al. (2007) compared soil organic C dynamics in soil under CA in sub-humid and semi-arid conditions in Zimbabwe and concluded that tillage disturbance was the dominant factor reducing $C$ stabilization and therefore organic matter build-up.

The low $\mathrm{P}$ concentration in the soil was expected given the low inherent P status of the soil (Grant, 1981; Nyamangara et al., 2000) and the suboptimal average fertilizer rates (less than $10 \mathrm{~kg} \mathrm{ha}^{-1} \mathrm{yr}^{-1}$ ) used by smallholder farmers in general and resource-constrained farmers in particular (Palm et al., 2004). In higher rainfall regions the availability of the limited soil $\mathrm{P}$ reserves for plant uptake is further reduced by high acidity (low $\mathrm{pH}$ ) conditions which promote the reaction of $P$ with elements such as $\mathrm{Al}$ and $\mathrm{Fe}$ to form insoluble chemical compounds not available for plant uptake (Nyamangara et al., 2000).

\subsection{Maize grain yield}

Generally maize grain yield was highly variable but higher in CA plots compared with conventional tillage plots at lower yield levels $\left(<2.5 \mathrm{t} \mathrm{ha}^{-1}\right)$. At higher yield levels, conventionally tilled plots recorded higher yield compared with CA plots, especially in 2009/ 10 season (Fig. 4). Since all farmers practiced minimum tillage but not all crop rotation and or mulching, it was possible to compare the effect of (i) mulching, (ii) rotation, and (iii) mulching + rotation in the CA plots. When no basal and topdressing fertilizer were applied, mulching (Table 1a), rotation (Table $1 \mathrm{~b}$ ) and mulchin$\mathrm{g}+$ rotation (Table $1 \mathrm{c}$ ) had a negative yield effect compared with 

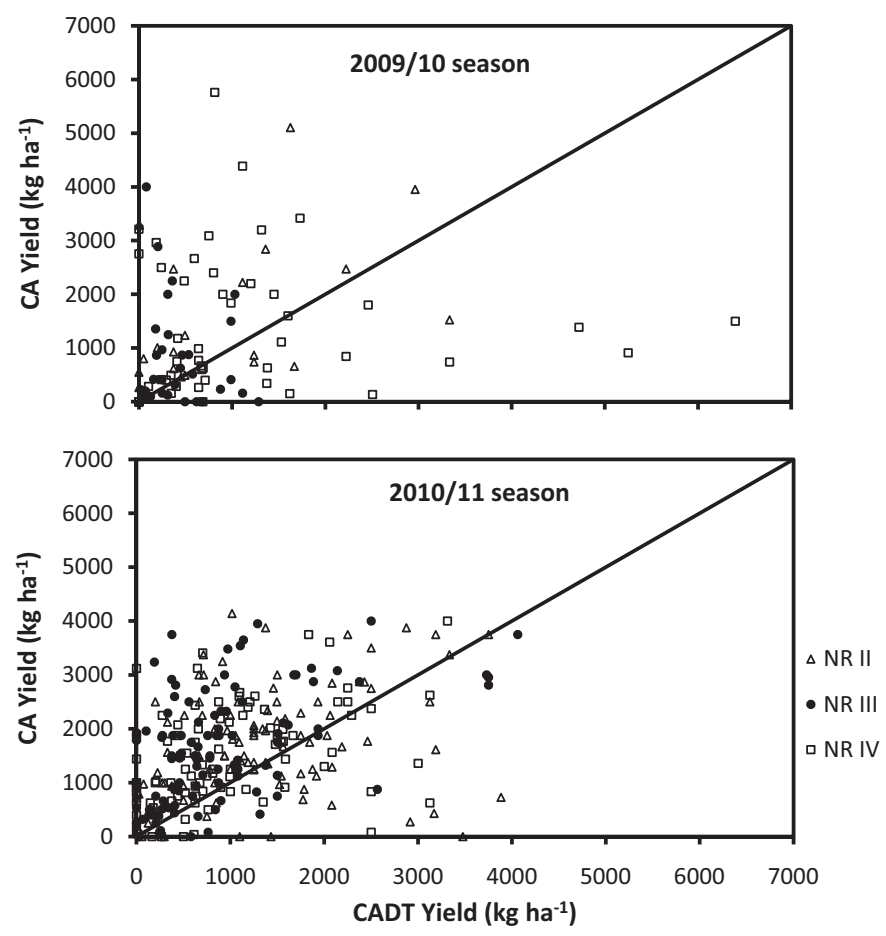

Fig. 4. Comparison of maize yields in paired plots under conventional tillage and CA in smallholder areas on sandy loam soils under sub-humid and semi-arid conditions in Zimbabwe.

minimum tillage alone. Mulching had the most negative effect ( $48 \%$ yield decrease) (Table $1 \mathrm{a}$ ) rotation the least (28\% yield decrease) (Table 1b). However addition of basal NPKS fertilizer and/or mineral $\mathrm{N}$ topdressing had a positive effect (7-69\%) on grain yield compared with minimum tillage alone and the effect was highest when both CA principles were practiced (Table 1a-c). Therefore the hypothesis that mulching and crop rotation increase maize grain yield was accepted when mineral fertilizer was added and rejected when the fertilizer was not added.

The relatively higher grain yield in NR IV in 2009/10 season, which is relatively less nutrient-mined due to frequent droughts which cause total crop failure every 2 out of 5 years, was attributed to above average and well distributed rainfall. Despite the documented environmental benefits of CA (Thierfelder and Wall, 2009; Marongwe et al., 2010), the higher yields in the CA plots at low yield levels may not justify the increased labor associated with the practice compared with conventional tillage (Mazvimavi and Twomlow, 2009). The high labor demand emanates from manual preparation of planting basins and increased frequency of weeding. Most of the smallholder farmers in the survey did not rotate maize with legumes, a practice proven to increase maize yields under CA (Rusinamhodzi et al., 2011). The yield increase due to crop rotation is attributed to a combined effect of multiple factors that include reduced pest and weed infestations, improved water use efficiency, good soil quality (e.g. higher organic C) and greater biological activity.

Most farmers who mulched their CA plots imported the mulch from other fields in order to achieve the 30\% soil surface cover threshold implying that the production level was too low to satisfy the CA mulch and livestock feed requirements. However, a metaanalysis study using world-wide data reported no clear benefits of mulching on maize grain yield (Rusinamhodzi et al., 2011). Our study suggests that without mineral $\mathrm{N}$ fertilizer the high C-to-N ratio cereal mulch can reduce yield possibly due to immobilization of soil N (Table 1a-c). In Zimbabwe resource-constrained farmers were targeted by non-governmental organizations and these only applied fertilizer to their CA plots when it was supplied for free.
This may explain the observed rapid decline in the number of smallholder farmers engaged in CA-based cropping when free inputs were no longer supplied (Mazvimavi and Nyamangara, 2010). Therefore, CA should be targeted at farmers with access to mineral fertilizer in order to ensure higher yield and long-term adoption.

\section{Conclusions}

The hypothesis that $\mathrm{CA}$ improves soil $\mathrm{pH}$, organic $\mathrm{C}$ and total $\mathrm{P}$ was rejected. The hypothesis that mulching and crop rotation increase maize grained yield was only accepted when mineral fertilizer was added implying that the benefits of mulching and legume-based crop rotation on maize grain yield can only be realized in CA systems when mineral fertilizer is available. The promotion of CA should therefore target farmers with access to mineral fertilizer in order to ensure yield benefits. There is need to boost crop productivity so that farmers can generate enough crop residues for both surface mulching and livestock feed, and to develop legume markets so that farmers can allocate more land to legume crops and thereby establish functional legume-based crop rotation systems.

\section{Acknowledgments}

The authors are grateful to the Protracted Relief Program (PRP), which was funded by a consortium of donors and managed by GRM International, for sponsoring this study.

\section{References}

Anderson, J.M., Ingram, J.S.I., 1993. Soil organic matter and organic carbon. In: Anderson, J.M., Ingram, J.S.I. (Eds.), Tropical Soil Biology and Fertility. CAB International, Wallingford, U.K., pp. 62-66.

Chivenge, P.P., Murwira, H.K., Giller, K.E., Mapfumo, P., Six, J., 2007. Long-term impact of reduced tillage and residue management on soil carbon stabilisation: implications of conservation agriculture on contrasting soils. Soil \& Tillage Research 94, 328-337.

Fuentes, M., Govaerts, B., Hidalgo, C., Etchevers, J., Gonzalez-Martin, I., HernandezHierro, J.M., Sayre, K.D., Dendooven, L., 2010. Organic carbon and stable ${ }^{13} \mathrm{C}$ isotope in conservation agriculture and conventional systems. Soil Biology \& Biochemistry 42, 551-557.

Grant, P.M., 1981. The fertilization of sandy soils in peasant agriculture. Zimbabwe Agricultural Journal 78, 169-175.

Haggblade, S., Tembo, G., 2003. Early evidence on conservation farming in Zambia. A paper prepared for the International Workshop on "Reconciling Rural Poverty and Resource Conservation: Identifying Relationships and Remedies". Cornell University, Ithaca, NY, p. 30.

Hazarika, S., Parkinson, R., Bol, R., Dixon, L., Russel, P., Allen, D.A., 2009. Effect of tillage system and straw management on organic matter dynamics. Agronomy for Sustainable Development 20, 525-533.

IUSS Working Group WRB, 2007. World Reference Base for Soil Resources 2006, first update 2007. World Soil Resources Reports No. 103. FAO, Rome.

Madejón, E., Murillo, J.M., Moreno, F., López, M.V., Arrue, J.L., Alvaro-Fuentes, J., Cantero, C., 2009. Effect of long-term conservation tillage on soil biochemical properties in Mediterranean Spanish areas. Soil \& Tillage Research 105, 55-62.

Mapfumo, P., Giller, K.E., 2001. Soil Fertility Management Strategies and Practices by Smallholder Farmers in Semiarid Areas of Zimbabwe. ICRISAT/FAO, Patancheru, Andhra Pradesh, India.

Masvaya, E.N., Nyawasha, R.W., Zingore, S., Nyamangara, J., Delve, R.J., Giller, K.E., 2010. Spatial soil fertility variability and plant nutrient uptake: a case of two smallholder farming areas in contrasting agro-ecological zones in Zimbabwe. Nutrient Cycling in Agroecosystems 88, 111-112.

Mazvimavi, K., Nyamangara, J., 2010. Dynamics in conservation agriculture farming adoption intensity, 2007-2010. Presentation to the CA Task Force Meeting, Institute of Agricultural Engineering, Harare, 7 December 2010. ICRISAT, Bulawayo.

Mazvimavi, K., Twomlow, S., 2009. Socioeconomic and institutional factors influencing adoption of conservation farming by vulnerable households in Zimbabwe. Agricultural Systems 101, 20-29.

Marongwe, L.S., Kwazira, K., Jenrich, M., Thierfelder, C., Kassam, A., Friedrich, T. 2010. An African success: the case of conservation agriculture in Zimbabwe. International Journal of Agricultural Sustainability 9, 153-161.

Metay, A., Oliver, R., Scopel, E., Douzet, J.M., Aloisio Alves Moreira, J., Maraux, F., Feigl, B.J., Feller, C., 2007. $\mathrm{N}_{2} \mathrm{O}$ and $\mathrm{CH}_{4}$ emissions from soils under conventional and no-till management practices in Goiānia (Cerrados, Brazil). Geoderma 141, 78-88. 
Mtambanengwe, F., Mapfumo, P., 2005. Organic matter management as an underlying cause for soil fertility gradients on smallholder farms in Zimbabwe. Nutrient Cycling in Agroecosystems 73, 227-243.

Mugwira, L.M., Nyamangara, J., 1998. Organic carbon and plant nutrients in soils under maize in Chinamhora Communal Area. In: Bergström, L., Kirchmann, H. (Eds.), Carbon and Nutrient Dynamics in Natural and Agricultural Ecosystems. CAB International, UK, pp. 15-21.

Murillo, J.R., Moreno, F., Pelegrin, F., Fernandez, J.E., 1998. Responses of sunflower to traditional and conservation tillage under rainfed conditions in southern Spain. Soil \& Tillage Research 43, 233-241.

Nyamangara, J., Gotosa, J., Mpofu, S.E., 2001. Effects of cattle manure on the structure and water retention capacity of a granitic sandy soil in Zimbabwe. Soil \& Tillage Research 62, 157-162.

Nyamangara, J., Makarimayi, E., Masvaya, E.N., Zingore, S., Delve, R., 2011. Effect of soil fertility management strategies and resource-endowment on spatial soil fertility gradients, plant nutrient uptake and maize growth at two smallholder areas, north-western Zimbabwe. The South African Journal of Plant and Soil 28, $1-10$.

Nyamangara, J., Mugwira, L.M., Mpofu, S.E., 2000. Soil fertility status in the communal areas of Zimbabwe in relation to sustainable crop production. Journal of Sustainable Agriculture 16, 15-29.

Okalebo, R.J., Gathua, K.W., Woomer, P.L., 1993. Laboratory Methods of Soil and Plant Analysis: A Working Manual, 2nd edition. TSBF/UNESCO-ROSTA, Marve EPZ Ltd., Kenya, p. 88.

Palm, C.A., Machado, P.O.A., Mahmood, T., Melillo, J., Murrel, S.T., Nyamangara, J. Scholes, M., Sisworo, E., Olesen, J.E., Pender, J., Stewart, J., Galloway, J.N., 2004
Societal responses for addressing nitrogen fertilizer needs: balancing food production and environmental concerns. In: Mosier, A.R., Syers, J.K., Freney, J.R. (Eds.), Agriculture and the Nitrogen Cycle: Assessing the Impacts of Fertilizer Use on Food Production and the Environment. SCOPE/Island Press, USA, pp. 71-89.

Pala, M., Ryan, J., Diekmann, J., Singh, M., 2008. Barley and vetch yields from dryland rotations with varying tillage and residue management under Mediterranean conditions. Experimental Agriculture 44, 559-570.

Reeves, D.W., 1997. The role of soil organic matter in maintaining soil quality in continuous cropping systems. Soil \& Tillage Research 43, 131-167.

Rusinamhodzi, L., Rufino, M.C., van Wijk, M., Nyamangara, J., Corbeels, M., Giller, K.E., 2011. A meta analysis of long term effects of conservation agriculture on maize grain yield under rain-fed conditions. Agronomy for Sustainable Development, http://dx.doi.org/10.1007/s13593-011-0040-2.

Tittonell, P., Vanlauwe, B., Leffelar, P.A., Sherpherd, K.D., Giller, K.E., 2005. Exploring diversity in soil fertility management of smallholder farms in Western Kenya: II. Within-farm variability in resource allocation, nutrient flows and soil fertility status. Agriculture Ecosystems \& Environment 110, 166-184.

Thierfelder, C., Wall, P.C., 2009. Effects of conservation agriculture techniques on infiltration and soil water content in Zambia and Zimbabwe. Soil \& Tillage Research 105, 217-227.

Vincent, V., Thomas, R.G., 1960. An Agricultural Survey of Southern Rhodesia, Part 1: Agro-ecological Survey. Government Printers, Salisbury.

Zingore, S., Delve, R.J., Nyamangara, J., Giller, K.E., 2008. Multiple effects of manure: the key to maintenance of soil fertility and restoration of depleted sandy soils on African smallholder farms. Nutrient Cycling in Agroecosystems 80, 267-282. 